\title{
Quality Evaluation of Different Species of Edible Bamboo Shoots
}

\author{
Sangita Sood, Shivani Walia, Anil Sood \\ Department of Food Science, Nutrition and Technology \\ CSKHPAU, Palampur, India
}

\begin{abstract}
Bamboo shoots are having immense potential of being used as health foods because of their richness in nutritional value. Four varieties of Edible Bamboo shoots viz. Phyllostachys pubescens $\left(V_{1}\right)$, Dendrocalamus asper $\left(V_{2}\right)$, Dendrocalamus hemilltoni $\left(V_{3}\right)$ and Bambusa bambos $\left(V_{4}\right)$ were used for the estimation of Quality attributes by using standard methodology. Results of the study showed that moisture, ash and fat contents of the four varieties was varied from 88.82-92.06; 0.80-0.90 per cent 0.29-0.39 per cent in $V_{1}, V_{2}, V_{3}$ and $V_{4}$, respectively. Whereas, fiber content was established as $1.29,1.20,1.50$ and 1.42 per cent in $V_{1}, V_{2}, V_{3}$ and $V_{4}$ respectively. The values for protein content were calculated as 3.70, 3.43, 3.50 and 3.72 for $V_{1}, V_{2}, V_{3}$ and $V_{4}$ respectively. Shoots are also good source of minerals. Values for selenium and magnesium were 6.80, 6.70, 6.80 and 1.10 and 3.40, 4.50, 3.90 and $3.50 \mathrm{mg} / 100 \mathrm{~g}$, respectively for $V_{1}, V_{2}, V_{3}$ and $V_{4}$.
\end{abstract}

Keywords: Bamboo shoots, Nutritional value, Fat and Fiber contents

\section{INTRODUCTION}

Bamboo shoots are the emerging shoots which are just $12 \mathrm{~cm}$ above the ground. This part of the bamboo is edible for human beings. Bamboo is one kind of vegetable for its being pollution free, low in fat, high in edible fibre and rich in mineral elements and considerable proportion of polyunsaturated fatty acids. Thus, indicating a potential use as a source of therapeutic values. Bamboos play an important role in daily life of rural people especially tribals in numerous ways. The edible part of Bamboo i.e. shoot has an immense medicinal values. Presence of high quality vitamins, carbohydrates, proteins and minerals in Bamboo shoot and their easy availability to common man may help in solving nutritional deficiency of rural poor (Tripathi 1998). Bamboo shoots are rich in various nutrients, therefore an effort was made to evaluate some varieties of bamboo shoots for their nutrient content.

\section{Materials AND Methods}

In the present study, four different varieties of Bamboo shoots viz. Phyllostachys pubescens $\left(\mathrm{v}_{1}\right)$, Dendrocalamus asper $\left(\mathrm{v}_{2}\right)$, Dendrocalamus hemilltoni $\left(\mathrm{v}_{3}\right)$ and Bambusa bambos $\left(\mathrm{v}_{4}\right)$ were used for Quality evaluation.

Bamboo shoots were procured from the Division of Biotechnology, Institute of Himalayan Bioresource Technology (IHBT), Palampur. Sheaths were manually removed. The shoots were washed under running tap water to remove adhered hairs and dust particles.

Methods used for the estimation were standard methods suggested by AOAC,1990 and Ranganna 1995.

\section{RESUlTS AND DiSCUSSION}

To ascertain quality parameters of Bamboo shoots, physical and chemical parameters were tested. The results are depicted in pertinent tables.

\section{Physical Evaluation}

The physical parameters of Quality evaluation included length, weight of shoot, width of shoot, weight of edible portion, peel per cent and per cent edible proportion. The relevant data have been depicted in Table 1. 


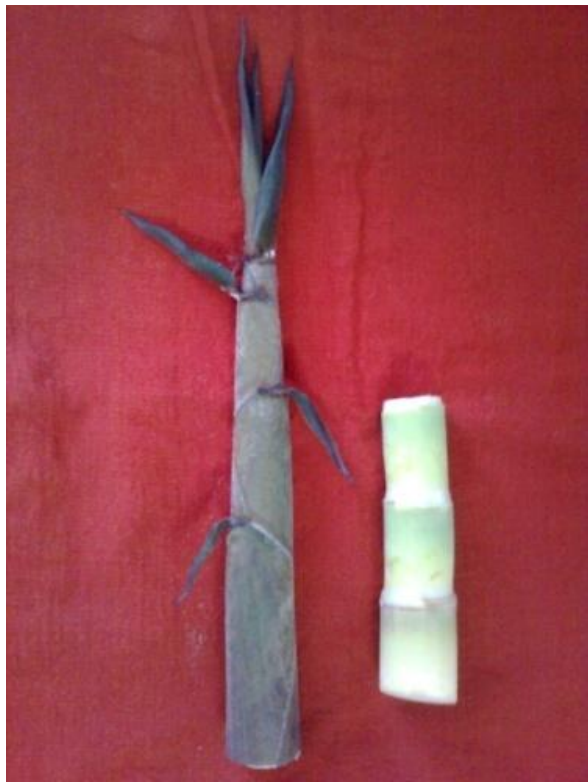

Dendrocalamus asper

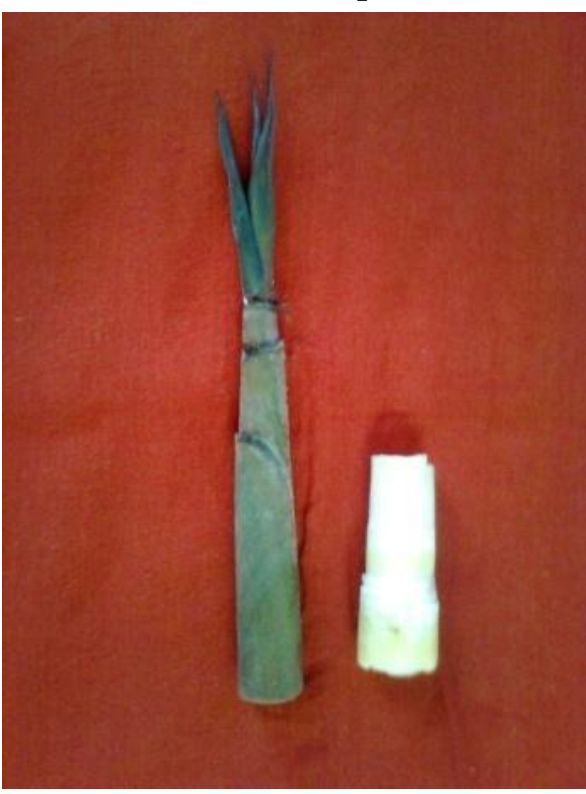

Phyllostachys pubescens

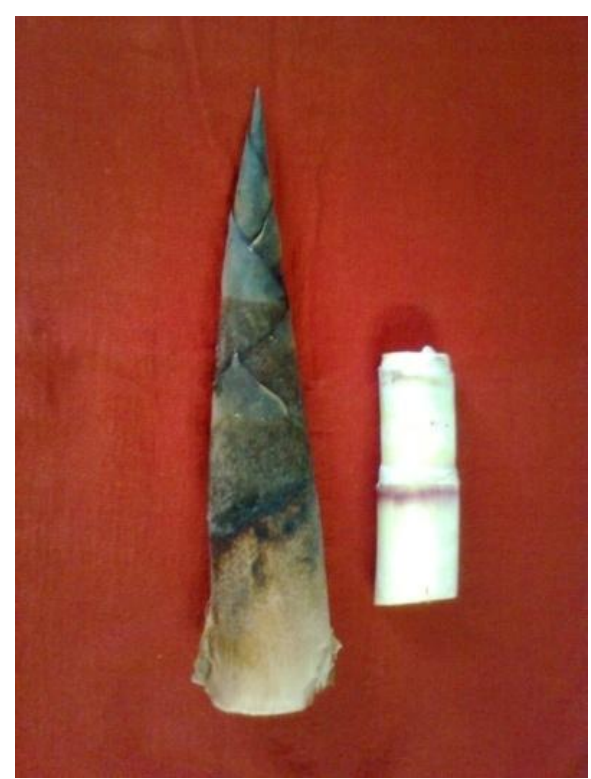

\section{Dendrocalamus hemilltoni}

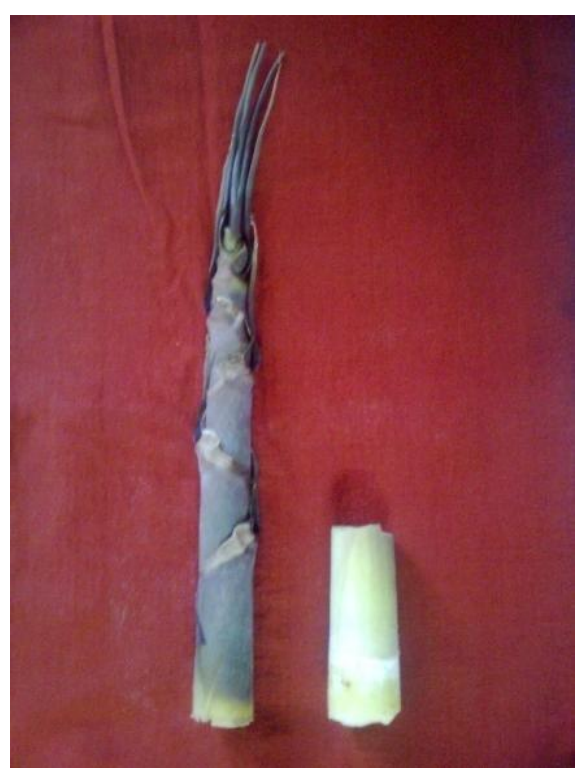

Bambusa bambos

Plate 1: Different varieties of Bamboo shoots used for Quality evaluation

As is evident from the table, the shoot length was calculated as 24.56, 24.30, 26.50; $25.66 \mathrm{~cm}$ for varieties $\mathrm{V}_{1}, \mathrm{~V}_{2}, \mathrm{~V}_{3}$ and $\mathrm{V}_{4}$, respectively, while width was estimated as $5.0,4.5,7.0$ and $3.5 \mathrm{~cm}$ respectively with an average of $5.0 \mathrm{~cm}$ for the four varieties. Average weight for $\mathrm{V}_{1}, \mathrm{~V}_{2}, \mathrm{~V}_{3}$ and $\mathrm{V}_{4}$ was calculated as $275,200,300$ and $250 \mathrm{~g}$ respectively. The weight of the shoots varies with the size of the shoots.

Table 1. Physical Parameters of Bamboo Shoots

\begin{tabular}{|c|c|c|c|c|c|}
\hline Varieties & $\begin{array}{c}\text { Length } \\
(\mathbf{c m s})\end{array}$ & $\begin{array}{c}\text { Width } \\
(\mathbf{c m s})\end{array}$ & Wt. of shoot $(\mathbf{g})$ & $\begin{array}{c}\text { Peel } \\
(\boldsymbol{\%})\end{array}$ & $\begin{array}{c}\text { Edible portion } \\
(\boldsymbol{\%})\end{array}$ \\
\hline $\mathbf{V}_{\mathbf{1}}$ & 24.56 & 5.00 & 275 & 70.90 & 29.10 \\
\hline $\mathbf{V}_{\mathbf{2}}$ & 24.30 & 4.50 & 200 & 67.50 & 32.50 \\
\hline $\mathbf{V}_{\mathbf{3}}$ & 26.50 & 7.00 & 300 & 66.67 & 33.33 \\
\hline $\mathbf{V}_{\mathbf{4}}$ & 25.66 & 3.50 & 250 & 70.00 & 30.00 \\
\hline Mean & 25.25 & 5.00 & 256 & 68.77 & 31.23 \\
$\mathbf{C D}$ & 0.25 & 0.04 & 1.17 & 0.17 & 0.81 \\
\hline
\end{tabular}

Edible portion is obtained after subtracting the weight of the peel from the weight of the shoot and data is expressed in the same table. Per cent edible portion was recorded to be 29.10, 32.50, 33.33 and 30.00 for same set of shoots. 


\section{Chemical/Nutritional Evaluation}

Quality evaluation of Bamboo shoots was also affirmed on the basis of chemical analysis of varietal constituents viz., pH, Total Soluble Solids ( ${ }^{\circ}$ Brix), Acidity (\%), Ascorbic acid (mg/100 g), Sugars and proximate composition.

\section{Moisture}

Estimation of moisture is widely used in testing the quality of foods. As the dry matter in food materials is inversely related to the amount of moisture it contains and it is directly related to stability, eating quality, nutritive value and processing requirements.

A perusal of data in Table 2 illustrates that four varieties of Bamboo shoots viz. Phyllostachys pubescens, Dendrocalamus asper, Dendrocalamus hemilltoni and Bambusa bambos contain 92.06, 88.82, 91.06 and 89.05 per cent moisture respectively.

Table 2. Chemical Parameters of Bamboo Shoots

\begin{tabular}{|c|c|c|c|c|c|c|c|c|c|}
\hline Varieties & $\begin{array}{c}\text { Moisture } \\
(\boldsymbol{\%})\end{array}$ & $\begin{array}{c}\text { Ash } \\
(\boldsymbol{\%})\end{array}$ & $\begin{array}{c}\text { Protein } \\
(\boldsymbol{\%})\end{array}$ & $\begin{array}{c}\text { Fat } \\
(\boldsymbol{\%})\end{array}$ & $\begin{array}{c}\text { Fibre } \\
(\boldsymbol{\%})\end{array}$ & $\begin{array}{c}\text { NDF } \\
(\boldsymbol{\%})\end{array}$ & $\begin{array}{c}\text { ADF } \\
(\boldsymbol{\%})\end{array}$ & $\begin{array}{c}\text { Lignin } \\
(\boldsymbol{\%})\end{array}$ & $\begin{array}{l}\text { TFFA* } \\
(\boldsymbol{\%})\end{array}$ \\
\hline $\mathbf{V}_{\mathbf{1}}$ & 92.06 & 0.90 & 3.70 & 0.39 & 1.29 & 2.62 & 2.17 & 0.56 & 0.13 \\
\hline $\mathbf{V}_{\mathbf{2}}$ & 88.82 & 0.80 & 3.43 & 0.30 & 1.20 & 2.18 & 1.81 & 0.47 & 0.12 \\
\hline $\mathbf{V}_{\mathbf{3}}$ & 91.06 & 0.81 & 3.50 & 0.29 & 1.50 & 2.54 & 2.08 & 0.49 & 0.11 \\
\hline $\mathbf{V}_{\mathbf{4}}$ & 89.05 & 0.85 & 3.72 & 0.25 & 1.42 & 2.32 & 2.03 & 0.53 & 0.11 \\
$\mathbf{C D}$ & 0.16 & 0.08 & 0.01 & 0.01 & 0.18 & 0.03 & 0.01 & 0.02 & NS \\
\hline
\end{tabular}

*TFFA=Total Free Amino Acids

The variations in moisture content of four different varieties may be because of various factors like stage of maturity, time of harvesting, agro-climatic conditions and the varietal differences. Bhatt et al. (2005) reported 94.70 per cent moisture which is on the higher side when compared with the present values. Later on, Nirmala et al. (2007) reported the values in Dendrocalamus asper to be 89.40 per cent, close to the present result. A bit variation could be due to the maturity of samples coupled with the agro-climatic and varietal variations.

\section{Ash}

Ash content gives an index to the mineral matter in food materials. From the Table 5 it is clear that ash content obtained in four different varieties viz. Phyllostachys pubescens, Dendrocalamus asper, Dendrocalamus hemilltoni and Bambusa bambos was recorded in terms of 0.90, 0.80, 0.81 and 0.85 per cent. This shows that the varieties of $\mathrm{V}_{2}$ and $\mathrm{V}_{3}$ attain almost close value for ash content, whereas, $\mathrm{V}_{1}$ and $\mathrm{V}_{4}$ had slightly on higher side. The results of present study are close to the values reported by Kumbhare and Bhargava (2007) who reported 0.90 per cent ash in Bambusa nutans and 0.80 per cent in Dendrocalamus asper and Bambusa vulgaris. The results are in line with present study. It can be safely concluded that the ash content is the inherited quality of Bamboo and least affected by varietal variations, topography and cultural practices.

\section{Protein}

The estimation of crude protein reflects that total nitrogenous and non-nitrogenous proteins present in the sample. The values for protein in four different varieties were ranged as 3.43-3.72 per cent.

Later on in 2009, Satya et al. reported the values on the higher side i.e. 3.90 per cent. Bhatt et al. (1996) had also attained higher value (4.16) per cent in Bambusa vulgaris. This variation could be due to genetic variation of the varieties or because of the use of different conversion factor.

Fat

Table 2 depicts the per cent fat in four varieties of Bamboo shoots. The variety $\left(\mathrm{V}_{1}\right)$ attained the maximum (0.39) and $\mathrm{V}_{4}$ minimum (0.25) per cent. Whereas $\mathrm{V}_{2}$ and $\mathrm{V}_{3}$ had the intermediate values i.e. 0.30 and 0.29 per cent. The results are in close agreement with Sharma et al 1998 who reported the fat content to be 0.20 per cent. Anonymous (2004) reported 0.50 per cent at content which is considerably on higher side of the present study.

This significant variation might be due to the basic genetic make-up of the Bamboos. The light falling on the surface also affects the composition and its quality characteristics. 


\section{Crude fibre}

Crude fibre includes all materials which are indigestible in humans and non-reminants and also used as an index of maturity. Table 2 illustrate that the values for four different varieties as $1.29,1.20,1.50$ and 1.42 per cent, respectively. Whereas, Kumbhare and Bhargava (2007) reported 0.76 per cent crude fibre which is on lower ebb. The variation might be due to varietal difference as well as the stage of maturity. The values for parameters under test are in line to the cited ones. This gives credence to the present findings.

\section{NDF, ADF, Lignin and total free amino acid}

Fractions of fibre i.e. NDF, ADF and Lignin were estimated in four varieties of Bamboo shoots. The values for NDF were reported as 2.62, 2.18, 2.54 and 2.32 per cent, respectively for $V_{1}, V_{2}, V_{3}$ and $V_{4}$ while the values for ADF were 2.17, 1.18, 2.08 and 2.03 for the same set of Bamboo shoots. The values for Lignin were estimated as $0.56,0.47,0.49$ and 0.53 per cent. The results are in line to Nirmala et al (2008) who reported 2.65 per cent NDF, 2.15 per cent ADF and 0.56 per cent Lignin in Bamboo shoots. The values for parameters under reference are in agreement to the cited ones. Thus this gives credence to the present findings. Total free amino acids varied from 0.11 to 0.13 in four varieties. The results are similar to the findings of Kumbhare and Bhargava (2007).

\section{$p H$}

$\mathrm{pH}$ determines the acidity or alkalinity of a sample thereby, affecting the colour, flavor and texture of food. $\mathrm{pH}$ of four varieties of Bamboo shoots was calculated as 5.7, 6.2, 5.9 and 6.5 for $\mathrm{V}_{1}, \mathrm{~V}_{2}, \mathrm{~V}_{3}$ and $\mathrm{V}_{4}$ respectively, and reported in Table 3. The data is in line with Devi and Singh (1986) who reported an average value for $\mathrm{pH} 6.7$ in Bamboo shoots. The slight variation could be varietal variation.

Table 3. Nutritional Parameters of Bamboo Shoots

\begin{tabular}{|c|c|c|c|c|c|c|c|}
\hline \multirow[t]{2}{*}{ Varieties } & \multirow[t]{2}{*}{ pH } & \multirow{2}{*}{$\begin{array}{c}\text { TSS } \\
\left({ }^{0} \text { Brix }\right)\end{array}$} & \multirow{2}{*}{$\begin{array}{c}\text { Acidity } \\
(\%)\end{array}$} & \multirow{2}{*}{$\begin{array}{l}\text { Ascorbic acid } \\
(\mathrm{mg} / \mathbf{1 0 0 g})\end{array}$} & \multicolumn{3}{|c|}{ Sugars $(\%)$} \\
\hline & & & & & Total & Reducing & $\begin{array}{c}\text { Non- } \\
\text { reducing }\end{array}$ \\
\hline$V_{1}$ & 5.70 & 1.20 & 0.32 & 3.20 & 1.11 & 0.72 & 0.37 \\
\hline $\mathbf{V}_{2}$ & 6.20 & 1.60 & 0.16 & 4.80 & 1.22 & 0.81 & 0.43 \\
\hline $\mathbf{V}_{\mathbf{3}}$ & 5.90 & 0.90 & 0.28 & 5.30 & 0.80 & 0.41 & 0.37 \\
\hline$V_{4}$ & 6.50 & 0.80 & 0.15 & 4.90 & 0.74 & 0.34 & 0.38 \\
\hline Mean & 6.07 & 1.12 & 0.28 & 4.55 & 0.97 & 0.57 & 0.38 \\
\hline CD & 0.54 & 0.01 & 0.16 & 0.02 & 0.08 & 0.03 & 0.023 \\
\hline
\end{tabular}

TSS

Total soluble solids consist of sugars and acids. It is also an index of the maturity of raw fruits and vegetables.

As evident from the Table 3, the values for TSS were recorded as 1.2, 1.6, 0.9 and 0.8 degree Brix in $\mathrm{V}_{1}, \mathrm{~V}_{2}, \mathrm{~V}_{3}$ and $\mathrm{V}_{4}$, respectively. No reference could be cited in literature on this parameter to support the present study.

\section{Acidity}

The acidity of Bamboo is largely due to the presence of citric acid which is a predominant acid present in Bamboo shoots.

The Table 3 reports the values for per cent acidity in Phyllostachys pubescene, Dendrocalamus asper, Dendrocalamus hemilltoni and Bambusa bambos was calculated as 0.32, 0.16, 0.28 and 0.35 per cent. The results obtained are in close agreement with Devi and Singh (1986) who reported 0.20 per cent acidity in Bamboo shoots.

\section{Ascorbic acid}

Table 3 depicts that the values for ascorbic acid $(\mathrm{mg} / 100 \mathrm{~g})$ were $3.2,4.8,5.3$ and $4.9 \mathrm{mg} / 100 \mathrm{~g}$ for $\mathrm{V}_{1}$, $\mathrm{V}_{2}, \mathrm{~V}_{3}$ and $\mathrm{V}_{4}$, respectively, Bhatt and associates in the year 2005 also reported $5.3 \mathrm{mg} / 100 \mathrm{~g}$ ascorbic acid and thereafter, Nirmala et al. in 2007 also reported $3.2 \mathrm{mg} / 100 \mathrm{~g}$ ascorbic acid in Bamboo shoots. The results in the present study are in accordance to them. 


\section{Sugars}

The sugars impart the sweetness in the products. Data regarding the values for Total sugars, Reducing sugars and Non- reducing sugars has been depicted in Table 6. Next parameter is Total sugars, the values calculated were $1.11,1.22,0.80$ and 0.74 for $V_{1}, V_{2}, V_{3}$ and $V_{4}$ respectively. Devi and Singh (1986) reported 0.78 percent Total sugars. Reducing sugar content was estimated as $0.72,0.81,0.41$ and 0.34 for same set of Bamboo shoots. Khumbhare and Bhargava (2007) reported 1.05 per cent reducing sugars in Bambusa nutans. The difference in values is due to varietal difference. The nonreducing sugars content was estimated as $0.37,0.43,0.37$ and 0.38 for $V_{1}, V_{2}, V_{3}$ and $V_{4}$, respectively thus corroborating the pre findings.

\section{Mineral content of Bamboo shoots}

The mineral elements which were analyzed in the four varieties of Bamboo shoots include Calcium, Copper, Sodium, Potassium, Phosphorus, Selenium and Magnesium.

Table 4 depicts that the values for calcium were $13.00,11.00,15.00$ and $12.00 \mathrm{mg} / 100 \mathrm{~g}$ for $\mathrm{V}_{1}, \mathrm{~V}_{2}, \mathrm{~V}_{3}$ and $\mathrm{V}_{4}$, respectively. However, Copper content was estimated to be $0.19,0.25,0.29$ and $0.15 \mathrm{mg} / 100 \mathrm{~g}$ for $V_{1}, V_{2}, V_{3}$ and $V_{4}$, respectively. Sodium was estimated as 4.00, 4.10, 4.80 and 3.50mg/100g in $V_{1}$, $\mathrm{V}_{2}, \mathrm{~V}_{3}$ and $\mathrm{V}_{4}$ respectively.

Whereas, potassium (mg/100 g) was found to be 459.00, 503.00, 533.00, 521.00 for four varieties. Phosphorus was calculated as 55.00, 59.00, 61.00 and 65.00. Values for selenium and magnesium were 6.80, 6.70, 6.80 and 1.10 and $3.40,4.50,3.90$ and $3.50 \mathrm{mg} / 100 \mathrm{~g}$, respectively for $\mathrm{V}_{1}, \mathrm{~V}_{2}, \mathrm{~V}_{3}$ and $\mathrm{V}_{4}$.

Table 4. Mineral Content of Bamboo Shoots

\begin{tabular}{|c|c|c|c|c|c|c|c|}
\hline Varieties & $\begin{array}{c}\text { Calcium } \\
(\mathbf{m g} / \mathbf{1 0 0 g})\end{array}$ & $\begin{array}{c}\text { Copper } \\
(\mathbf{m g} / \\
\mathbf{1 0 0 g})\end{array}$ & $\begin{array}{c}\text { Sodium } \\
(\mathbf{m g} / \\
\mathbf{1 0 0 g})\end{array}$ & $\begin{array}{c}\text { Potassium } \\
(\mathbf{m g} /\end{array}$ & $\begin{array}{c}\text { Phosphorus } \\
\mathbf{1 0 0 g})\end{array}$ & $\begin{array}{c}\text { Selenium } \\
(\mathbf{m g} / \mathbf{1 0 0 g})\end{array}$ & $\begin{array}{c}\text { Magnesium } \\
(\mathbf{m g} /\end{array}$ \\
\hline $\mathbf{V}_{\mathbf{1}}$ & 13.00 & 0.19 & 4.00 & 459.00 & 55.00 & 6.80 & 3.40 \\
\hline $\mathbf{V}_{\mathbf{2}}$ & 11.00 & 0.25 & 4.10 & 503.00 & 59.00 & 6.70 & 4.50 \\
\hline $\mathbf{V}_{\mathbf{3}}$ & 15.00 & 0.29 & 4.80 & 533.00 & 61.00 & 6.80 & 3.90 \\
\hline $\mathbf{V}_{\mathbf{4}}$ & 12.00 & 0.15 & 3.50 & 521.00 & 65.00 & 1.10 & 3.50 \\
$\mathbf{C D}$ & 0.10 & 0.09 & 0.80 & $\mathrm{NS}$ & $\mathrm{NS}$ & 0.12 & 0.08 \\
\hline
\end{tabular}

In the year 2007, Jetvig analyzed Bamboo samples for their mineral composition. The values for calcium (10mg), magnesium (2mg), phosphorus (45mg), potassium (402mg) and sodium (3mg). the slight difference could be due to varietal difference and agro-climatic reasons.

\section{Conclusion}

From the foregoing discussion it is inferred that bamboo shoots are good source of all the nutrients. Amongst all the varieties Dendrocalamus hemilltoni which is grown abundantly in the region was found best in terms of quality parameters. These shoots can be exploited for the development of various value added products to add new dimension in the market.

\section{REFERENCES}

Anonymous. 2004. www.Bamboo shoots.com

AOAC 1990. Approved methods of association of official analytical chemists. Washington D.C. U.S.A. $11^{\text {th }}$ edition. P- 240.

Bhargava A, Kumbhare V, Srivastava A and Sahai A. 1996. Bamboo parts and seeds for additional source of nutrition. Journal of Food Science and Technology 33(2) : 145- 146.

Bhatt BP Singh K and Singh A. 2005. Nutritional values of some commercial edible Bamboo species of North Eastern Himalayan Region, India. Journal of Bamboo and Rattan 4(2): 111-124.

Devi SP and Singh HT. 1986. Studies on the chemical and nutritional changes of Bamboo shoots during fermentation. Journal of Food Science and Technology 23: 338- 339

Jegtvig Shereen. 2007. www.Bamboo shoots.com.

Kumbhare Vishakha and Bhargava Alka. 2007. Effect of processing on nutritional value of central Indian Bamboo shoots.part- 1. Journal of Food Science and Technology 44(1): 29- 31. 
Nirmala C, David E and Sharma ML. 2007. Changes in nutrient components during ageing of emerging juvenile Bamboo shoots. International Journal of Food Science and Nutrition : 1-7.

Nirmala C, Sharma ML and David E.2008. A comparative study of nutrients components of freshly harvested, fermented and canned Bamboo shoots of Dendrocalamus giganteus Munro. The Journal of America Bamboo Society. 21(1): 33- 39.

Ranganna S. 1995. Handbook of analysis and quality control for fruits and vegetables products. $3^{\text {rd }}$ edition

Roohani E David, Richa and Nirmala C. 2001. Nutritive value of Edible shoots of two Exotic Indian Bamboos. Acta Hortculturae. 752:1

Satya Santosh, M. Bal, Lalit SP and Naik SN. 2009. Food quality and safety aspect (a review). Trends in food science and technology. 21(4) : 181-189

Sharma S, Dhaliwal, YS and Kalia M. 1998. Candied Apples : a new Perspective. Journal of Food Science and Technology $35: 79-82$

Tripathi YC. 1998. Food and nutrition potential of Bamboo. MFP- News. 8(1) : 10-11 